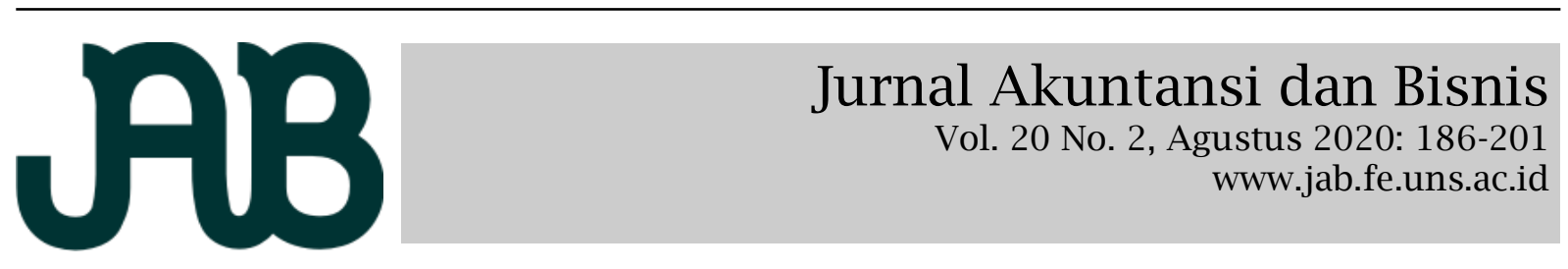

\title{
PELAPOR KECURANGAN: PERSEPSI KERUGIAN PERSONAL, STATUS PELANGGAR, DUKUNGAN DAN PERLINDUNGAN ORGANISASI
}

\author{
ERNA SETIANY ${ }^{1}$ \\ ANNISA HAKIM ZAMZAMI² (annisa.hakim@mercubuana.ac.id) \\ SRI WAHYU AGUSTININGSIH ${ }^{3}$
}

1,2 Program Studi Akuntansi, Fakultas Ekonomi dan Bisnis, Universitas Mercu Buana, Indonesia

${ }^{3}$ Program Studi Manajemen, Fakultas Ekonomi, Universitas Veteran Bangun Nusantara, Indonesia

\begin{abstract}
A B S T R A C T
Employee participation as a whistleblower is still low. This is due to various factors that make employees reluctant to report the fraud they have encountered, such as perceptions of personal loss and the status of offenders. On the other hand, some factors allow employees to blow the whistle, such as organizational support and protection. Thus, this study examines personal cost factors, offender status, organizational support and protection against internal whistleblowing intentions. Respondents of this study were 112 accounting students who have worked in both the private and government sectors in DKI Jakarta. The results showed that only organizational protection had a significant effect on internal whistleblowing intentions. Meanwhile, personal costs, violator status, and organizational support have no significant effect on internal whistleblowing intentions.

Keywords: whistleblowing intention, personal costs, offender status, organizational support and protection

Partisipasi karyawan menjadi whistleblower masih tergolong rendah. Hal ini disebabkan oleh berbagai faktor yang membuat karyawan enggan untuk melaporkan kecurangan yang mereka temui, seperti persepsi kerugian pribadi dan status pelanggar. Di lain sisi terdapat faktor yang memungkinkan karyawan untuk melaporkan kecurangan, seperti dukungan dan proteksi organisasi. Dengan demikian, penelitian ini menguji faktor persepsi kerugian pribadi, status pelanggar, dukungan dan proteksi organisasi terhadap niat pelaporan kecurangan internal. Responden penelitian ini adalah 112 mahasiswa akuntansi yang sudah bekerja baik sektor swasta maupun pemerintahan di DKI Jakarta menggunakan kuisioner dan dianalisis menggunakan SEM berbasis kovarian dengan Smart PLS 2.0. Hasil penelitian menunjukkan bahwa hanya perlindungan organisasi yang signifikan berpengaruh terhadap niat pelaporan kecurangan internal. Sedangkan persepsi kerugian pribadi, status pelanggar, dan dukungan organisasi tidak signifikan berpengaruh terhadap niat pelaporan kecurangan internal.

Kata Kunci: whistleblowing intention, persepsi kerugian pribadi, status pelanggar, dukungan dan proteksi organisasi
\end{abstract}

\section{PENDAHULUAN}

Skandal kecurangan yang melibatkan perusahaan-perusahaan besar di Amerika Serikat, seperti Enron, WorldCom, Anderson, dan Tyco menyebabkan keyakinan bahwa kecurangan yang sama dapat ditemukan hampir di setiap organisasi. Oleh sebab itu, untuk mengatasi permasalahan Sarbanes-Oxley Act (SOA) memandatkan setiap organisasi mengadopsi whistleblowing system (Saud, 2016)

Whistleblowing system merupakan sebuah program yang memungkinkan indi- vidu untuk melaporkan kecurangan. SOA mengharapkan whistleblowing system dapat meliputi permasalahan akuntansi, pengendalian internal, dan audit (MesmerMagnus \& Viswesvaran, 2005; Near \& Miceli, 1995). Menurut Mesmer-Magnus dan Viswesvaran (2005) kemungkinan besar melaporkan kecurangan adalah orang internal organisasi seperti karyawan, karena karyawan terlibat langsung dalam aktivitas organisasi. Mereka biasanya menemukan kecurangan sebelum auditor internal dan eksternal. Namun, karyawan yang 
menemukan kecurangan terkadang menghadapi dilema (Liyanarachchi \& Newdick, 2009). Hal ini disebabkan oleh konsekuensi yang mungkin mereka terima jika melaporkan kecurangan tersebut kepada otoritas organisasi atau luar organisasi. Konsekuensi tersebut dapat berupa kehilangan pekerjaan, penurunan pangkat, dan penurunan kualitas pekerjaan, sedangkan dari publik dapat berupa pembunuhan karaktek dan bahkan lebih buruk lagi (Cassematis \& Wortley, 2013; Chang, Wilding \& Shin, 2017; Mesmer-Magnus \& Viswesvaran, 2005). Oleh sebab itu, tahun 2010 SEC membuat program whistleblower yang dapat dimanfaatkan bagi pelapor untuk melaporkan kecurangan dengan rasa aman dari pembalasan dan memberikan reward atas laporannya tersebut. Setelah sembilan tahun program whistleblower berjalan terdapat 72 orang pelapor dengan jumlah reward \$387 juta dollar (Banks \& Filoromo, 2020).

Sebaliknya, di Indonesia, undangundang yang mengatur secara khusus mengenai pelapor kecurangan belum ada. Peraturan mengenai pelapor kecurangan secara implisit terdapat pada UndangUndang No.13 Tahun 2006 tentang Perlindungan Korban dan Saksi. Selain itu juga terdapat pada Surat Edaran Makamah Agung No.4 Tahun 2011 tentang Perlakuan terhadap Pelapor Tindak Pidana dan Saksi Pelaku yang Bekerja Sama. Namun pada praktiknya masih belum sepenuhnya dilaksanakan secara luas di lembaga-lembaga pemerintahan atau lembaga negara, institusi-institusi publik atau sektor swasta (Semendawai Santoso, Wagiman, Omas, Susilaningtias \& Wiryawan, 2011). Hal ini dapat dilihat dari kasus Susno Duadji, Agus Condro, Vincent, dan Khairiansyah dipenjarakan dan paling buruk dibunuh (Semendawai et al., 2011). Hal ini dapat disimpulkan bahwa peran whistleblower belum cukup optimal. Oleh sebab itu, menjadi penting untuk mengkaji lebih jauh mengenai faktor-faktor yang memengaruhi individu untuk melaporkan kecurangan.

Sejumlah penelitian terdahulu telah mengkaji faktor-faktor yang memengaruhi niat individu untuk melaporkan tindak kecurangan, di antaranya adalah faktor in- dividual (Ahmad, Smith \& Ismail, 2012; Brink, Lowe \& Victoravich, 2013, 2017), personal cost dan organisasi (Cho \& Song, 2015) faktor situasional (Kaplan, Pany, Samuels \& Zhan, 2012) dan faktor-faktor lain yang dapat memengaruhi niat individu dalam melaporkan kecurangan.

Persepsi kerugian pribadi (personal cost) merupakan salah satu penentu pengambilan keputusan pelaporan kecurangan. Jika individu menemukan minimnya kerugian yang diperoleh, kemungkinan untuk melaporkan kecurangan akan lebih besar. Sebaliknya jika persepsi kerugian personal lebih tinggi kemungkinan akan melaporkan kecurangan yang mereka temui akan lebih kecil (Schultz, Johnson, Morris \& Dyrne, 1993). Sebagaimana yang dijelaskan dalam teori prososial bahwa keputusan melaporkan kecurangan bukan berdasarkan prososial altruistik, tetapi berdasarkan kepentingan pribadi. Ketika individu merasakan kemungkinan menderita atau biaya kerugian yang besar, seperti pembalasan atau sanksi yang mereka terima, individu tersebut cenderung mengurungkan niatnya melaporkan kecurangan (Liyanarachchi \& Newdick, 2009). Hasil temuan (Cho \& Song, 2015; Hanif \& Odiatma, 2017) menunjukkan bahwa persepsi kerugian personal signifikan berpengaruh negatif terhadap pelaporan kecurangan. Berbeda dengan hasil penelitian (Busra, Ahyaruddin, \& Agustiawan, 2019; Helmayunita, 2018; Indriani, Yulia, Nadirsyah \& Ariska, 2019; Nurkholis, 2015; Setyawati, Ardiyani \& Sutrisno, 2015) yang menyatakan bahwa personal cost tidak signifikan berpengaruh terhadap niat pelaporan kecurangan. Hal ini menunjukkan bahwa masih ada hasil penelitian yang tidak konsisten. Oleh sebab itu, peneliti melakukan pengujian kembali mengenai hubungan persepsi kerugian personal dan niat pelaporan kecurangan.

Tidak jauh berbeda dengan persepsi kerugian pribadi, status pelanggar juga merupakan faktor yang dapat menurunkan niat individu untuk melaporkan kecurangan. Hal ini dihubungkan dengan retaliasi yang akan dihadapi individu ketika berniat melaporkan kecurangan (Cortina \& Magley, 2003). Jika pelaku kecurangan 
memiliki kedudukan yang lebih tinggi, akan lebih sulit untuk diungkapkan, karena pelaku lebih mungkin melakukan pembalasan dengan memberi tekanan dan ancaman, atau berkaitan dengan keputusan strategis organisasi (Cortina \& Magley, 2003). Dengan kata lain, tindakan pelaporan kecurangan perlu dipahami oleh semua anggota organisasi, agar peran whistleblower dapat berperan secara optimal di organisasi. Beberapa penelitian sebelumnya telah menguji faktor situasi terhadap pelaporan kecurangan seperti (Cortina \& Magley, 2003; Winardi, 2015) menyatakan bahwa status pelanggar signifikan berpengaruh terhadap niat pelaporan kecurangan. Namun hasil dari temuan (Ahmad et al., 2012; Zamzami, Safira \& Mahmudah, 2020) menyatakan tidak signifikan. Oleh sebab hasil penelitian menunjukkan tidak konsisten, maka dilakukan pengujian kembali.

Berbeda dengan persepsi kerugian personal dan status pelanggar, adanya dukungan dan proteksi organisasi dapat meningkatkan keinginan individu untuk melaporkan kecurangan (Valentine \& Godkin, 2019). Eisenberger, Malone \& Presson (2016) menjelaskan perspektif dukungan organisasi didefinisikan sebagai keyakinan karyawan mengenai sejauh mana organisasi menghargai kontribusi dan kepedulian mereka terhadap kesejahteraan mereka. Dukungan organisasi dapat berupa perlakuan adil, sumber daya yang dibutuhkan, kepuasan dalam bekerja. Ketika organisasi memprioritaskan pentingnya whistleblowing dan memutuskan untuk sepenuhnya mendukung perilaku serta melindungi whistleblower, upaya tersebut dapat dianggap sebagai jenis dukungan organisasi sehingga dapat meningkatkan niat pelaporan kecurangan dalam organisasi. Near \& Miceli (1986) menjelaskan bahwa kurangnya dukungan dari pengawas dan manajemen puncak mengurangi niat melaporkan kecurangan. Oleh sebab itu, para pemimpin etis yang mendukung dan mendorong perilaku etis memfasilitasi motivasi untuk melaporkan kecurangan (Bhal \& Dadhich, 2011). Iklim organisasi yang kondusif juga secara positif terkait dengan kemungkinan bersuara (Cho \& Song, 2015; Lavena, 2014).
Berbeda dengan penelitian sebelumnya seperti Ahmad et al., (2012) dan Cortina \& Magley (2003) yang menguji karakteristik organisasi dan Cho \& Song (2015) menguji persepsi dukungan dan proteksi terhadap niat pelaporan kecurangan yang dimediasi oleh persepsi kerugian pribadi (personal cost) penelitian ini menguji langsung persepsi dukungan dan proteksi organisasi terhadap niat pelaporan kecurangan mahasiswa akuntansi kelas karyawan.

Berdasarkan penelitian terdahulu yang secara konsisten mengidentifikasi pelapor kecurangan sebagai sumber deteksi fraud yang paling penting (ACFE, 2016; Andon, Free, Jidin, Monroe \& Turner, 2018). Namun demikian, tidak cukup tersedia insentif bagi pelapor potensial, khususnya profesional akuntan yang kompeten untuk mengidentifikasi dan melaporkan fraud (Pope \& Lee, 2013), maka penelitian ini menguji faktor persepsi kerugian pribadi, status pelanggar, dukungan dan proteksi organisasi terhadap niat pelaporan kecurangan pada mahasiswa akuntansi sebagai karyawan yang bekerja di perusahaan sektor swasta dan pemerintahan wilayah DKI Jakarta. Mahasiswa akuntansi yang sudah bekerja sebagai responden diharapkan mereka memahami keputusan etis sebagaimana yang mereka dapatkan di perguruan tinggi. Hal ini didukung oleh pernyataan Utami \& Indriawati (2006) bahwa pentingnya peran dunia pendidikan dalam menciptakan sumber daya manusia yang cerdas dan bermoral. Dengan demikian, memahami prinsip-prinsip good corporate governance yang disampaikan di perguruan tinggi akan membentuk sikap independen, transparan, adil, dan akuntabel harus dimiliki oleh semua pengelola organisasi, baik swasta maupun pemerintah.

Artikel ini terdiri dari beberapa poin utama, di bagian kedua menjabarkan teori untuk menghipotesiskan hubungan antara faktor-faktor yang memengaruhi niat pelaporan kecurangan; bagian ketiga menjabarkan metodologi penelitian dan data; bagian keempat menjabarkan analisis data dan pembahasan; bagian kelima menyajikan kesimpulan, keterbatasan, dan saran. 


\section{TINJAUAN PUSTAKA DAN PENGEM- BANGAN HIPOTESIS \\ Prososial}

Perilaku prososial merupakan suatu konflik pemikiran individu yang harus memilih antara ketenangan dirinya atau orang lain dalam konteks peran otoritas hukum diktat, kriteria, atau kewajiban formal lainnya (Eisenberg et al., 2016). Bentuk-bentuk dari perilaku prososial dapat berupa membantu, berbagi, menyumbang, bekerja sama, dan bertindak secara sukarela. Perilaku prososial memiliki harapan dapat menguntungkan, mensejahterakan, dan menjaga integritas orang lain tanpa mengharapkan imbalan dan penghargaan sosial (Brief \& Motowidlo, 1986). Hal ini merupakan bentuk pemahaman dari altruisme (altruism), yaitu sebuah hasrat individu untuk meningkatkan kesejahteraan yang lain sebagai tujuan akhirnya (Batson, 1983 dalam Dozier \& Miceli, 1985). Kriteria perilaku altruisme, yaitu a) tindakan berdasarkan tujuan itu sendiri dan tidak diarahkan pada keuntungan; b) tindakan secara sukarela; dan c) hasil tindakan baik.

Perilaku prososial mempunyai implikasi penting bagi organisasi, yaitu perilaku yang ditampilkan oleh anggota organisasi ditujukan kepada individu, kelompok, maupun organisasi tempat dia berinteraksi dengan membawa peran organisasionalnya dan dilakukan dengan tujuan menguntungkan individu, kelompok, atau organisasi tersebut (Brief \& Motowidlo, 1986). Tindakan prososial dalam organisasi dapat berupa kerjasama dengan individu lain dalam melindungi organisasi dari bahaya yang tidak terduga, mengusulkan perbaikan organisasi dan sebagainya. Dengan adanya perilaku prososial, anggota organisasi dapat meningkatkan kemampuan organisasi dalam bertahan dan mencapai tujuannya (Brief \& Motowidlo, 1986).

Pelaporan kecurangan merupakan salah satu bentuk dari perilaku prososial organisasi (Brief \& Motowidlo, 1986). Namun, pelaporan kecurangan bukan seutuhnya altruisme, karena tidak dapat memenuhi kriteria altruisme secara keseluruhan. Kriteria pertama, tindakan merupakan tujuan itu sendiri, seorang whistleblower tidak mempunyai motif untuk keun- tungan pribadi. Sebaliknya, whistleblower mungkin saja mencari keuntungan pribadi. Hal ini mungkin disebabkan oleh konsekuesi kecurangan yang memengaruhi mereka seraca langsung, seperti pelanggaran keselamatan kerja.

Kriteria kedua, tindakan dilakukan secara sukarela. Pelaporan kecurangan dapat berupa persyaratan pekerjaan atau bagian dari deskripsi kerja karyawan. Whistleblower lainnya mungkin bertindak karena sebagai profesional, mereka merasa terdorong untuk mematuhi standar etika yang diakui. Selain itu Near dan Miceli (1984) dalam Dozier \& Miceli (1985) menyatakan bahwa tidak semua tindakan pelaporan kecurangan dilakukan secara sukarela, baik yang profesional maupun tidak. Walaupun dengan cara yang sama, terkadang mereka memiliki harapan dan penghargaan dari tindakannya.

Kriteria ketiga sulit untuk dipenuhi, karena hasil pelaporan kecurangan mungkin tidak dipandang secara umum sebagai penilaian yang "baik". Pelaporan kecurangan dapat bertindak atas dasar kepedulian moral (Baumert, Halmburger \& Schmitt, 2013; Cailleba \& Charreire Petit, 2018; O'Sullivan \& Ngau, 2014; Skitka, 2012; Watts \& Ronald Buckley, 2017), sebaliknya Devine \& Aplin (1986) dalam (Dungan et al., 2019) berpendapat bahwa whistleblower bisa jadi bertindak karena kepentingan oportunistik untuk keuntungan pribadi atau balas dendam. Merujuk pada berbagai pandangan yang beragam tersebut maka kajian mengenai factor yang mendorong pelapor kecurangan menarik untuk diteliti.

Membuat keputusan prososial terkait dengan pelaporan kecurangan memiliki beberapa langkah. Pertama, anggota organisasi mempertimbangkan apakah aktivitas tersebut merupakan perbuatan yang salah. Kedua, anggota mempertimbangkan apakah tindakan tersebut membutuhkan suatu tindakan. Ketiga, anggota memutuskan apakah merasa bertanggung jawab terhadap tindakan tersebut. Keempat, anggota mempertimbangkan apakah tindakan yang tepat tersedia. Kelima, anggota mempertimbangkan apakah tindakan yang diambil memadai. Keenam, anggota mempertim- 
bangkan apakah manfaat yang diharapkan dari tindakan yang diambil lebih besar dari biaya yang dikeluarkanggree. Tahap ketujuh, apakah hasil pelaporan memuaskan? (Dozier \& Miceli, 1985). Oleh sebab itu terdapat factor yang meningkatkan dan menurunkan niat seseorang dalam melaporkan kecurangan.

\section{Whistleblowing}

Whistleblowing adalah pengungkapan yang dilakukan oleh individu yang masih bekerja atau sudah berhenti bekerja terhadap tindakan ilegal, tidak bermoral, atau praktik yang tidak sah di bawah kendali pekerjaan mereka, kepada seseorang atau organisasi yang mungkin dapat mempengaruhi tindakan tersebut (Near \& Miceli, 1986). Pelaporan kecurangan internal dan eksternal didasari oleh apakah karyawan memberikan informasi di dalam atau di luar organisasi. Whistleblower yang melaporkan tindakan kecurangan kepada otoritas dalam organisasi disebut dengan pelaporan kecurangan jalur internal. Sedangkan pelaporan kecurangan jalur eksternal melaporkan tindak kecurangan kepada organisasi yang mempunyai wewenang untuk melakukan pengoreksian tindak kecurangan (Near \& Miceli, 1986). Pope \& Lee (2013) menjelaskan bahwa pembalasan dendam berpengaruh terhadap jalur apa yang dipilih oleh whistleblower, apakah internal atau eksternal. Menurut MesmerMagnus \& Viswesvaran (2005) jalur pelaporan eksternal lebih mengancam dibandingkan jalur internal. Kecenderungan whistleblower yang menggunakan jalur eksternal sebelumnya telah menggunakan jalur pelaporan internal, namun laporan mereka tidak disambut. Oleh sebab itu, mereka menggunakan jalur eksternal. Sebaliknya, menggunakan jalur pelaporan internal memiliki manfaat bagi organisasi karena masalah internal organisasi tidak tersebar ke luar. Hal ini menegaskan bahwa masing-masing jalur pelaporan memiliki keunggulan dan kelemahan. Kaplan et al. (2012) menjelaskan bahwa terdapat perbedaan perilaku individu dalam menentukan pilihan jalur apa yang digunakan dalam melaporkan kecurangan berdasarkan kondisi yang mereka hadapi. Namun penelitian ini menguji jalur internal, karena akan melihat faktor internal organisasi, seperti persepsi karyawan terhadap dukungan dan perlindungan organisasi dalam melaporkan kecurangan.

\section{Pesepsi Kerugian Personal}

Persepsi kerugian pribadi merupakan salah satu penentu pengambilan keputusan pelaporan kecurangan (Akbar et al., 2016; Aliyah et al., 2015; Alleyne et al., 2013; Cho \& Song, 2015; Nurkholis, 2015; Setyawati et al., 2015; Winardi, 2015). Jika individu menemukan minimnya kerugian, kemungkinan untuk melaporkan kecurangan akan lebih besar. Sebaliknya jika persepsi kerugian personal lebih tinggi kemungkinan akan melaporkan kecurangan yang mereka temui akan lebih kecil (Schultz et al., 1993). Keputusan melaporkan kecurangan bukan berdasarkan altruisme tetapi berdasarkan kepentingan pribadi. Baumert et al. (2013) individu berperilaku etis berdasarkan situasi yg realitis untuk mereka hadapi. Dengan demikian persepsi kerugian pribadi dapat didefinisikan sebagai bahaya yang dirasakan atau ketidaknyamanan dihasilkan dari melaporkan kecurangan (Dalton \& Radtke, 2013). Dari perspektif individu, sanksi yang masuk akal dan pembalasan dendam dari pengawas atau rekan kerja mungkin merupakan faktor yang paling mengancam yang menghambat pengaduan. Dengan demikian, potensi ancaman pembalasan berkaitan erat dengan persepsi biaya pribadi.

Sebagaimana yang dinyatakan Cortina \& Magley (2003) bahwa tindakan pembalasan dapat menjadi dua kategori yaitu terkait pekerjaan dan sosial. Pembalasan terkait pekerjaan seringkali berwujud, formal, dan didokumentasikan dalam catatan ketenagakerjaan. Contohnya, pemecatan, pemindahan paksa, penurunan pangkat, penilaian kinerja yang buruk dan perkuisisi atau kesempatan kerja lembur. Hal ini biasanya berasal dari penyelia, manajer, dan karyawan lain yang memiliki wewenang untuk melakukan perubahan tersebut.

Kategori yang kedua pembalasan sosial yang kurang nyata. Hal ini mengacu 
pada perilaku antisosial, baik verbal maupun nonverbal yang tidak didokumentasikan, misanya pelecehan, pengucilan, menyalahkan, ancaman, dan bentuk negatif lainnya. Hal ini bertujuan untuk mengubah hubungan interpersonal pelapor dengan negatif. Perilaku ini dapat datang dari indiviu-individu dari setiap tingkat organisasi. Dengan demikian, setiap individu mempertimbangan kemungkinan pembalasan dendam untuk melaporkan kecurangan yang mereka temui.

Beberapa penelitian telah menunjukkan hubungan persepsi keruagian pribadi (personal cost) dengan niat pelaporan kecurangan seperti, Kaplan dan Whitecotton (2001) dalam (Cho \& Song, 2015) menemukan hubungan negatif antara persepsi kerugian personal dan niat whistleblowing. Reginald Gernaldo (2014) dalam (Cho \& Song, 2015) menunjukkan bahwa karyawan yang memiliki tingkat persepsi kerugian personal yang rendah lebih cenderung melaporkan kecurangan. Dengan demikian hipotesisnya sebagai berikut:

H1: Perceived personal cost berpengaruh terhadap internal whistleblowing intention

\section{Status Pelanggar}

Status merupakan suatu kedudukan individu dalam hubungannya dengan individuindividu lain disekelilingnya (Kamus Besar Bahasa Indonesia). Dengan demikian status pelanggar merupakan kedudukan individu yang melakukan pelanggaran dalam hubungannya dengan individu-individu lain di tempatnya bekerja. Dalam pelaporan kecurangan, status pelanggar dapat mempengaruhi sikap individu lain, apakah mendiamkannya saja atau memilih untuk melaporkannya (Ahmad et al., 2012). (Near \& Miceli, 1995) menghubungkan status dengan power yang dimiliki individu. Power yang dimaksud berupa kekuatan atas sumber daya yang mereka kendalikan dalam menjalankan organisasi. Seperti status dalam organisasi, tingkat pendidikan, dukungan dari atasan, keanggotaan dalam mayoritas atau basis kekuatan lainnya, yang meliputi keahlian, kharisma, reward, atau kekuasaan koersif. Dengan demikian individu yang mempunyai power lebih tinggi akan lebih berkuasa dan dapat menekan individu yang tidak mempunyai power atau yang memiliki power lebih rendah dalam organisasi.

Ahmad et al. (2012) menambahkan bahwa individu yang kurang berniat untuk melaporkan kecurangan karyawan yang memiliki power lebih besar dalam organisasi disebabkan oleh beberapa alasan: (1) Takut mendapatkan balasan atau retaliasi.; (2) Keberlangsungan organisasi bergantung pada pelaku tersebut, (3) Kemungkinan untuk mendapatkan konsekuensi negatif jika melaporkan pelaku lebih besar.

Dengan demikian whistleblower yang memiliki power lebih rendah daripada pelaku pelanggaran kurang berkeinginan untuk melakukan pelaporan kecurangan (Near \& Miceli, 1995). (Cortina \& Magley, 2003; Schultz et al., 1993; Winardi, 2015) menunjukkan hasil yang sama, bahwa status pelaku kecurangan mempengaruhi niat pelapor kecurangan, maka hipotesis penelitiannya adalah sebagai berikut:

H2: Wrongdoer status berpengaruh terhadap internal whistleblowing Intention

\section{Dukungan dan Perlindungan Organisasi}

Budaya dan respon organisasi terhadap whistleblowing sangat penting (KammeyerMueller et al., 2012; Ugaddan \& Park, 2019; Watts \& Ronald Buckley, 2015; Weaver, Reynolds, \& Brown, 2014). Hal ini dimulai dari intensitas moral pimpinan oraganisasi yang berdampak pada regulasi organisasi (Weaver et al., 2014). Regulasi organisasi yang berkaitan dengan whistleblowing dapat berupa dukungan dan perlindungan terhadap pelapor kecurangan. (Eisenberger et al., 2016) mendefenisikan dukungan organisasi sebagai keyakinan karyawan mengenai sejauh mana organisasi menghargai kontribusi dan kepedulian mereka terhadap kesejahteraan mereka. Dukungan organisasi dapat berupa perlakuan adil, sumber daya yang dibutuhkan, hingga kepuasan dalam bekerja (Rose, Brink \& Norman, 2018; Taylor \& Curtis, 2013; Zhang, Pany \& Reckers , 2013). Selain itu, membantu kapasitas pemecahan masalah dan manajemen stres seseorang dapat 
menjadi bentuk dukungan organisasi. Ketika organisasi memprioritaskan pentingnya whistleblowing dan memutuskan untuk sepenuhnya mendukung perilaku serta melindungi whistleblower, upaya tersebut dapat dianggap sebagai jenis dukungan organisasi (Eisenberger et al., 2016; Stubben \& Welch, 2020). Dengan demikian dapat memengaruhi pola pikir individu terhadap suatu perbuatan tidak etis (Urumsah, Wicaksono \& Hardinto, 2018) dan meningkatkan niat pelaporan kecurangan dalam organisasi (Alleyne, Hudaib \& Pike, 2013). Sebaliknya, Near \& Miceli (1986) menyatakan kurangnya dukungan dari pengawas dan manajemen puncak dapat mengurangi niat melaporkan kecurangan. Oleh sebab itu, para pemimpin etis yang mendukung dan mendorong perilaku etis memfasilitasi motivasi untuk melaporkan kecurangan (Bhal \& Dadhich, 2011). Iklim organisasi yang kondusif juga secara positif terkait dengan kemungkinan bersuara (Morrison \& Milliken, 2000 dalam Cho \& Song, 2015). Organisasi yang memiliki sistem perlindungan terhadap whistleblower membuktikan bahwa organisasi tersebut memiliki sistem pelaporan kecurangan yang baik (Saud \& Fauzi, 2019). Adanya perlindungan terhadap whistleblower, merupakan cara yang efektif untuk mendorong kebijakan whistleblowing da-

Tabel 1.

Karakteristik Responden

\begin{tabular}{lccr}
\hline \multirow{2}{*}{ Informasi } & \multicolumn{2}{c}{ General } \\
\cline { 3 - 4 } & & Total & \multicolumn{1}{c}{$\%$} \\
\hline \multirow{3}{*}{ Umur } & 21-30 tahun & 3 & 2,68 \\
& $31-40$ tahun & 15 & 13,39 \\
& 41-50 tahun & 7 & 6,25 \\
Jenis & $>$ 50 tahun & 5 & 4,46 \\
Kelamin & perempuan & 71 & 63,39 \\
& laki-laki & 41 & 36,61 \\
Pendidikan & SMA/MA/ & 44 & 39,29 \\
Terakhir & SMK & 7 & 6,25 \\
& S1 D2/D3 & 53 & 47,32 \\
Bekerja di & Semerintah & 9 & 8,04 \\
sektor & Swasta & 103 & 91,96 \\
\hline
\end{tabular}

lam organisasi (Pope \& Lee, 2013). Oleh sebab itu, dukungan dan perlindungan organisasi dapat meningkatkan niat pelaporan kecurangan oleh karyawan, karena karyawan merasa aman dengan keputusan yang akan mereka ambil (Alleyne et al., 2013). Sehingga good corporate governance dapat terlaksana dengan baik. Dengan demikian dapat dihipotesiskan sebagai berikut:

H3: Organizational Support berpengaruh terhadap internal whistleblowing intention

H4: Organizational Protection berpengaruh terhadap internal whistleblowing intention

Kerangka konseptual pada penelitian ini dapat dilihat pada gambar 1 .

Gambar 1.

Kerangka Konseptual Penelitian

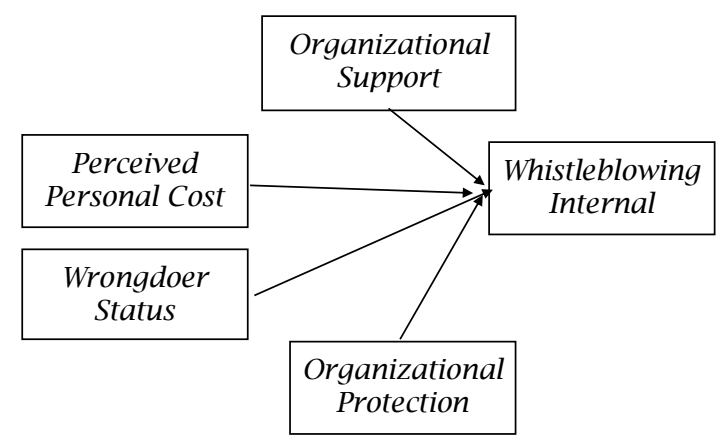

\section{METODE PENELITIAN}

Penelitian ini merupakan penelitian kuantitatif dengan metode klausal, yaitu menjelaskan hubungan sebab akibat antara variaben indenpenden dan variable dependen. Jenis data yang digunakan adalah crosssectional. Teknik pengambilan sampel penelitian ini melalui nonprobability sampling, yaitu mahasiswa akuntansi sebagai karyawan perusahaan di DKI Jakarta. Metode pengumpulan data menggunakan self administered survey yaitu kuesioner berbasis internet melalui google form. Data dianalisis menggunakan Structural Equation Model (SEM) berdasarkan kovarian dengan program SmartPLS 2.0. Hasil penggolongan karakteristik responden dapat dilihat pada Tabel 1. Terdapat 116 kuesioner yang ditanggapi responden. Namun, dari yang diisi responden tidak semua dapat dianalisis. 4 di antaranya out- 
lier sehingga yang dapat dianalisis hanya 112 kuesioner. Berdasarkan tingkat kesalahan 5 persen dari jumlah sampel 112 mencukupi corresponding power 0,80 . Karakteristik responden meliputi jenis kelamin, usia, pendidikan terakhir, dan tempat bekerja. Responden berjenis kelamin perempuan sebanyak 63 persen, laki-laki 37 persen. 73 persen responden berusia kisaran 21-30 tahun. Pendidikan terakhir responden sebagian besar S1, yaitu 47 persen. 92 persen bekerja di sektor swasta.

\section{Definisi Operasional dan Pengukuran Variabel}

Penelitian ini menggunakan kasus yang dikembangkan oleh Winardi (2015) untuk variabel status pelaku kecurangan, sedangkan untuk variabel persepsi kerugian personal, dukungan dan perlingungan organisasi, dan niat pelaporan kecurangan menggunakan model Cho \& Song (2015). Berbeda dengan Cho \& Song (2015) yang menjadikan persepsi dukungan dan proteksi organisasi sebagai faktor yang memengaruhi persepsi kerugian pribadi. Penelitian ini menguji persepsi dukungan dan proteksi organisasi terhadap niat pelaporan kecurangan sebagai faktor utama. Persepsi kerugian personal merupakan bahaya yang dirasakan atau ketidaknyamanan dihasilkan dari niat melaporkan kecurangan. Penelitian ini mengadopsi pertanyaan dari Cho \& Song (2015) (3 item pertanyaan). Status pelanggar adalah kedudukan individu yang melakukan pelanggaran dalam hubungannya dengan individu-individu lain di tempatnya bekerja. Penelitian ini mengembangkan model Near \& Miceli (1995) (4 item pertanyaan). Dukungan organisasi dan perlindungan organisasi dapat dipahami dari perspektif dukungan organisasi, yang didefinisikan sebagai keyakinan global karyawan mengenai sejauh mana organisasi menghargai kontribusi dan kepedulian mereka terhadap kesejahteraan mereka. Penelitian ini menggunakan model Cho \& Song (2015). Niat pelaporan kecurangan merupakan suatu intensitas pengungkapan suatu tindakan kecurangan karyawan. Model penelitian menggunakan model Cho \& Song (2015); Near \& Miceli (1986). Instrumen yang diadosi selanjutnya dimodifikasi sesuai dengan kebutuhan penelitian ini. Selanjutnya melakukan validitas isi secara individu dan kelompok pakar. Skala pengukuran menggunakan skala likert tipe 5 poin, dari 1 "sangat rendah" hingga 5 'sangat tinggi”.

Tabel 2.

Uji Validitas dan Reliabilitas

\begin{tabular}{|c|c|c|c|c|c|}
\hline Variabel & Item & $\begin{array}{c}\text { Outer } \\
\text { loading }\end{array}$ & $A V E$ & $\begin{array}{c}\text { Comp. } \\
\text { Reliability }\end{array}$ & $\begin{array}{l}\text { Cronbachs } \\
\text { Alpha }\end{array}$ \\
\hline \multirow{3}{*}{$\begin{array}{l}\text { Organizasional } \\
\text { Protection }\end{array}$} & OP1 & 0,784490 & \multirow{3}{*}{0,741169} & \multirow{3}{*}{0,895223} & \multirow{3}{*}{0,835032} \\
\hline & OP2 & 0,939215 & & & \\
\hline & OP3 & 0,852031 & & & \\
\hline \multirow{3}{*}{$\begin{array}{l}\text { Organizational } \\
\text { Support }\end{array}$} & OS1 & Reject & \multirow{3}{*}{1,000000} & \multirow{3}{*}{1,000000} & \multirow{3}{*}{1,000000} \\
\hline & OS2 & Reject & & & \\
\hline & OS3 & 1,000000 & & & \\
\hline \multirow{3}{*}{ Personal Cost } & PC1 & 0,896299 & \multirow{3}{*}{0,742150} & \multirow{3}{*}{0,895907} & \multirow{3}{*}{0,828314} \\
\hline & PC2 & 0,893130 & & & \\
\hline & PC3 & 0,790834 & & & \\
\hline \multirow{4}{*}{$\begin{array}{l}\text { Wrongdoer } \\
\text { Status }\end{array}$} & WS1 & 0,792815 & \multirow{4}{*}{0,725720} & \multirow{4}{*}{0,887835} & \multirow{4}{*}{0,820442} \\
\hline & WS2 & 0,856405 & & & \\
\hline & WS3 & 0,902870 & & & \\
\hline & WS4 & Reject & & & \\
\hline \multirow{3}{*}{$\begin{array}{l}\text { Whistleblowing } \\
\text { Internal }\end{array}$} & WBInt1 & 0,862704 & \multirow{3}{*}{0,766043} & \multirow{3}{*}{0,907594} & \multirow{3}{*}{0,852465} \\
\hline & WBlnt2 & 0,877995 & & & \\
\hline & WBlnt3 & 0,884870 & & & \\
\hline
\end{tabular}




\section{Uji Validitas}

Beberapa outer loading memiliki nilai lebih rendah dari 0,6 yaitu OS1, OS2, dan WS4. Dengan demikian, indikator tersebut dihapus untuk meningkatkan korelasi antar indikator dengan konstruknya. Setelah penghapusan indikator tersebut skor loading terbaru memiliki skor outer loading di atas 0,6, seperti yang dilihat pada Tabel 2 . Dengan demikian item-item pertanyaan memenuhi uji validitas.

\section{Uji Reliabilitas}

Tabel 2 menunjukkan nilai cronbach's alpha, composite reability, dan AVE lebih dari 0,7. Dengan demikian alat ukur yang digunakan dalam penelitian ini memiliki akurasi, konsistensi, dan ketepatan yang baik dalam melakukan pengukuran.

\section{Statistik Deskriptif}

Responden diberikan kasus mengenai kecurangan yang dilakukan dalam organisasi yang dilakukan oleh seorang atasan yang mungkin memberikan ancaman bagi responden dengan melaporkan kecurangan tersebut. Tabel 3 menunjukkan deskriptif persepsi responden responden terkait kasus kecurangan. Dukungan organisasi (organizational support) memiliki nilai ratarata 3,46 dengan standar deviasi 1,048. Nilai rata-rata OS tidak jauh berbeda dengan rata-rata teoritis. Hal ini menunjukkan bahwa responden organisasi tempat mereka bekerja tidak terlalu mendukung juga tidak terlalu mengabaikan pelaporan kecurangan. Sedangkan berbeda dengan perlindungan organisasi (organizational protection) terhadap pelapor kecurangan responden menjawab di atas rata-rata teoritis, yaitu 11,2232 dengan standar deviasi 2,63281. Hal ini menunjukkan bahwa responden merasakan adanya perlindungan dari organisasi terhadap pelapor kecurangan walaupun tidak begitu besar. Nilai rata-rata persepsi kerugian pribadi (personal cost) adalah 10,8393 dengan standar deviasi 2,69652. Rata-rata tanggapan responden sedikit di atas rata-rata teoritis. Hal ini menunjukkan bahwa melaporkan kecurangan atasan sedikit memiliki dampak merugikan kepadanya. Sedangkan rata-rata status pelanggar (wrongdoer status) adalah 9,7054 dengan standar deviasi 2,95503. Rata-rata tidak jauh berbeda dengan rata-rata teoritis, yang menunjukkan bahwa responden tidak terlalu berpendapat bahwa status atasan akan menghambat niatnya melaporkan kecurangan. Rata-rata niat pelaporan kecurangan secara internal (whistleblowing internal) adalah 12,2500 dengan standar deviasi 2,69652. Hal ini menunjukkan bahwa responden memiliki kecenderungan untuk melaporkan kecurangan secara internal atau pihak berwenang di dalam perusahaan.

Sejumlah penelitian terdahulu memperlihatkan bahwa faktor yang mengkhawatirkan whistleblower adalah mengalami tekanan dan bahkan pemberhentian dari pekerjaan (Bjørkelo, 2013; Dyck, Morse \& Zingales, 2010) dan mengalami pelecehan dan trauma emosional (Kenny, Fotaki \& Scriver, 2019; van der Velden, Pecoraro, Houwerzijl, \& van der Meulen, 2019). Hal ini menjadi faktor penting yang menyebabkan sejumlah peneliti terdahulu memperlihatkan hasil bahwa banyak orang menahan diri untuk tidak angkat bicara, bahkan dalam penelitian Bocchiaro, Zimbardo \& van Lange (2012) dan Dungan, Young \& Waytz (2019) memperlihatkan bahwa tingkat kesediaan menyampaikan kecurangan hanya berkisar pada angka 9\% dari seluruh responden. Dengan demikian terlihat bah-

Tabel 3.

Statistik Deskriptif

\begin{tabular}{llrrrrr}
\hline & N & \multicolumn{1}{c}{$\begin{array}{l}\text { Kisaran } \\
\text { Teoritis }\end{array}$} & \multicolumn{1}{c}{$\begin{array}{c}\text { Kisaran } \\
\text { Aktual }\end{array}$} & $\begin{array}{c}\text { Rata-rata } \\
\text { Teoritis }\end{array}$ & $\begin{array}{c}\text { Rata-rata } \\
\text { Aktual }\end{array}$ & $\begin{array}{c}\text { Standar } \\
\text { Deviasi }\end{array}$ \\
\hline OS & 112 & $1-5$ & $1-5$ & 3,00 & 3,46 & 1,048 \\
OP & 112 & $3-15$ & $5-15$ & 9,00 & 11,2232 & 2,63281 \\
WS & 112 & $3-15$ & $3-15$ & 9,00 & 9,7054 & 2,95503 \\
PC & 112 & $3-15$ & $4-15$ & 9,00 & 10,8393 & 2,69652 \\
WBInt & 112 & $3-15$ & $3-15$ & 9,00 & 12,2500 & 2,41430 \\
\hline
\end{tabular}


wa secara rata-rata hasil penelitian ini sesuai dengan penelitian terdahulu oleh Bocchiaro, Zimbardo, \& van Lange (2012).

\section{ANALISIS DAN PEMBAHASAN \\ Inner Model}

Model struktural dievaluasi dengan menggunakan $\mathrm{R}^{2}$ untuk mengukur tingkat variasi perubahan variabel indenpenden terhadap variabel dependen dan t-value untuk menguji signifikansi antar konstruk dalam model struktural (Jogianto, 2011). Model penelitian menguji hubungan persepsi kerugian personal, status pelanggar, dukungan organisasi, dan perlindungan organisasi terhadap pelaporan kecurangan internal, yang memiliki $\mathrm{R}^{2} \quad 0,208128$. Artinya, variabilitas pelaporan kecurangan internal yang dapat dijelaskan oleh variable persepsi kerugian personal, status pelanggar, dukungan organisasi, dan perlindungan organisasi adalah 20,81 persen, sedangkan sebagian besar dijelaskan oleh variabel lain di luar model yang diajukan.

\section{Goodness of Fit}

Tandenhau (2005) dalam Jogianto (2011) meyatakan bahwa goodness of fit dapat diukur dengan $\sqrt{ }$ AVExR $^{2}$. Hasil perhitungan goodness of fit penelitian ini adalah sebagai berikut :

$$
\sqrt{ } 0,79502 \times 0,208128=0,406774
$$

Hal ini menunjukkan bahwa model yang digunakan dalam penelitian ini memiliki goodness of fit yang besar.

\section{Path Coefficient}

Nilai koefisien path atau inner model menunjukkan tingkat signifikan dalam pengujian hipotesis yang ditunjukkan oleh niai t-statistik. Menurut Hair et al. (2010) nilai t-statistik harus di atas 1,96 untuk two -tailed dengan alpha 5 persen dan power 80 persen. Tabel 4 menjelaskan path coefficient model penelitian. H1 menjelaskan hubungan persepsi kerugian personal dengan niat pelaporan kecurangan jalur internal. Tabel 4 menunjukkan hubungan koefisien parameter H1 0,162929 yang berarti keseriusan persepsi kerugian pribadi berpengaruh positif terhadap niat pelaporan kecurangan jalur internal. Semakin individu merasakan kerugian personal yang akan dirasakan maka semakin berniat individu melaporkan kecurangan menggunakan jalur internal. Hasil dari nilai t-hitung menunjukkan 1,404200 yang lebih kecil dari t-tabel 1,96. Hal ini menjelaskan bahwa H1 tidak diterima.

H2 menjelaskan hubungan status pelanggar dengan niat pelaporan kecurangan jalur internal. Tabel 4 menunjukkan hubungan koefisien parameter $\mathrm{H} 2$ 0,147164 yang berarti status pelanggar berpengaruh positif terhadap niat pelaporan kecurangan jalur internal. Semakin tinggi status pelaku kecurangan maka semakin berniat individu melaporkan kecurangan menggunakan jalur internal. Hasil dari nilai t-hitung menunjukkan 1,133349 yang lebih kecil dari t-tabel 1,96. Hal ini menjelaskan bahwa $\mathrm{H} 2$ tidak diterima.

H3 menjelaskan hubungan dukungan organisasi dengan niat pelaporan kecurangan jalur internal. Tabel 4 menunjukkan hubungan koefisien parameter H3 0,187914 yang berarti dukungan organisasi berpengaruh positif terhadap niat pelaporan kecurangan jalur internal. Semakin tinggi dukungan organisasi dalam melaporkan kecurangan maka semakin berniat individu melaporkan kecurangan menggunakan jalur internal. Hasil dari nilai

Tabel 4

Path Coefficient

\begin{tabular}{cccccr}
\hline & $\begin{array}{c}\text { Original } \\
\text { Sample (O) }\end{array}$ & $\begin{array}{c}\text { Sample } \\
\text { Mean (M) }\end{array}$ & STDEV & STERR & $\begin{array}{c}\text { T Statistics } \\
(/ O / S T E R R /)\end{array}$ \\
\hline OP -> WB & 0,261369 & 0,264575 & 0,113840 & 0,113840 & 2,295933 \\
OS -> WB & 0,187914 & 0,181258 & 0,100308 & 0,100308 & 1,873365 \\
PC $>$ WB & 0,162929 & 0,174655 & 0,116030 & 0,116030 & 1,404200 \\
WS -> WB & 0,147164 & 0,164805 & 0,129849 & 0,129849 & 1,133349 \\
\hline
\end{tabular}


t-hitung menunjukkan 1,873365 yang lebih kecil dari t-table 1,96. Hal ini menjelaskan bahwa $\mathrm{H} 3$ tidak diterima.

H4 menjelaskan hubungan perlindungan organisasi dengan niat pelaporan kecurangan jalur internal. Tabel 4 menunjukkan hubungan koefisien parameter H3 0,261369 yang berarti perlindungan organisasi berpengaruh positif terhadap niat pelaporan kecurangan jalur internal. Semakin tinggi perlindungan organisasi terhadap pelapor kecurangan maka semakin berniat individu melaporkan kecurangan menggunakan jalur internal. Hasil dari nilai t-hitung menunjukkan 2,295933 yang lebih besar dari t-tabel 1,96. Hal ini menjelaskan bahwa H4 diterima. Ouput dari model penelitian secara keseluruhan diringkas pada gambar 2 .

\section{Pembahasan}

Graham (1986) menyatakan bahwa persepsi kerugian pribadi merupakan salah satu penentu pengambilan keputusan pelaporan kecurangan. Jika individu menemukan minimnya kerugian, kemungkinan untuk melaporkan kecurangan akan lebih besar. Sebaliknya jika persepsi kerugian personal lebih tinggi kemungkinan akan melaporkan kecurangan yang mereka temui akan lebih kecil (Schultz et al., 1993). Hasil penelitian ini menunjukkan bahwa persepsi kerugian personal berhubungan positif dengan niat pelaporan kecurangan. Sebagaimana yang dinyatakan oleh Gernaldo (2014) dalam Cho \& Song (2015) bahwa karyawan yang memiliki tingkat persepsi kerugian personal yang rendah lebih cenderung melaporkan kecurangan. Dilihat dari nilai rata-rata aktual personal cost responden di atas rata-rata teoritis, namun hasil analisis menunjukkan bahwa persepsi kerugian personal tidak signifikan berpengaruh terhadap niat pelaporan kecurangan. Hasil penelitian ini sejalan dengan temuan (Busra et al., 2019; Helmayunita, 2018; Nurkholis, 2015; Setyawati et al., 2015; Winardi, 2015). Hal ini dapat disebabkan oleh perbedaan objek dan kondisi responden yang berbeda dari temuan (Cho \& Song, 2015) yang menyatakan personal cost signifikan berpengaruh negatif terhadap niat pelaporan kecurangan.

Status merupakan suatu kedudukan individu dalam hubungannya dengan individu-individu lain disekelilingnya. Dengan demikian status pelanggar merupakan kedudukan individu yang melakukan pelanggaran dalam hubungannya dengan individu-individu lain di tempatnya bekerja. Dalam pelaporan kecurangan, status pelanggar dapat memengaruhi sikap individu lain, apakah mendiamkannya saja atau memilih untuk melaporkannya (Ahmad, 2011). Near \& Miceli (1995) menghubungkan status dengan power yang dimiliki individu. Power yang dimaksud berupa kekuatan atas sumber daya yang

Gambar 2.

Output Model Penelitian

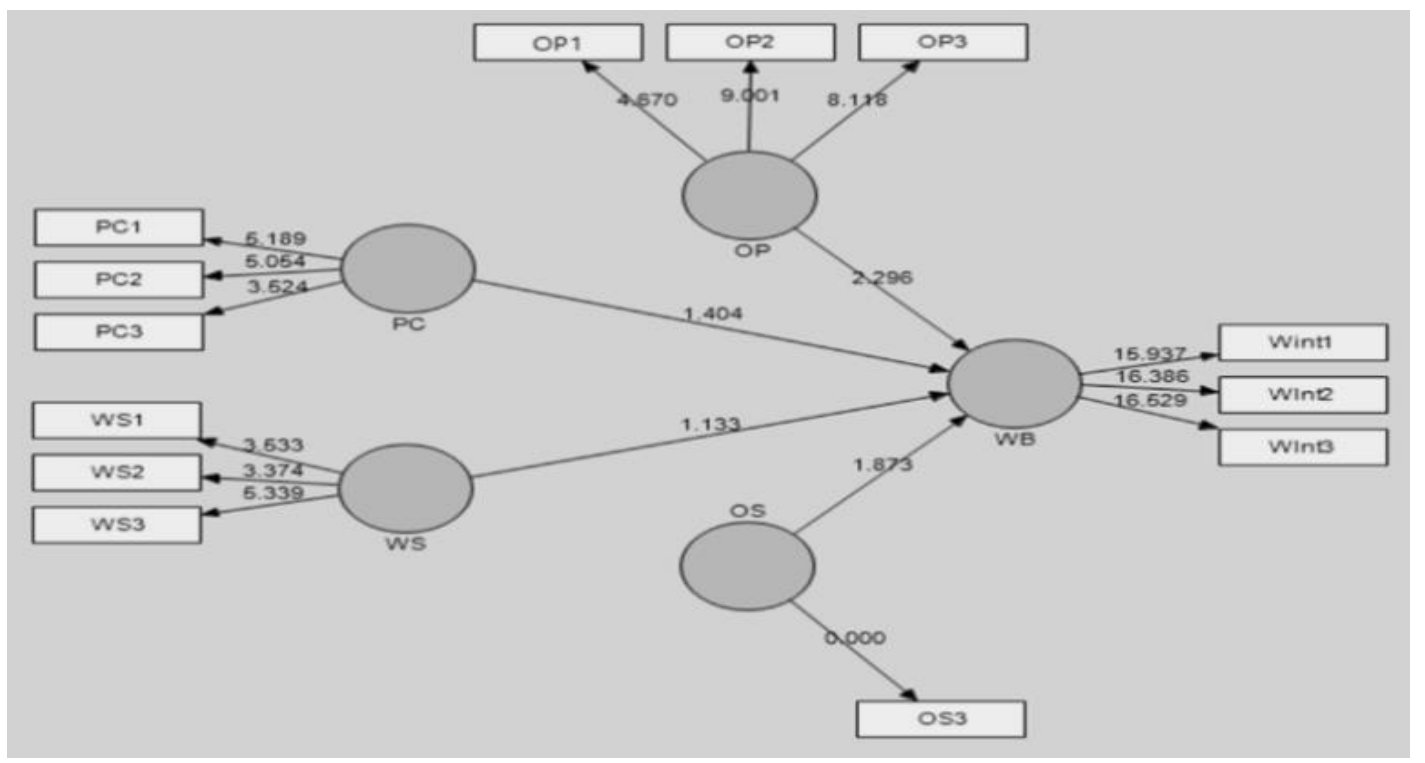


mereka kendalikan dalam menjalankan organisasi. Seperti status dalam organisasi, tingkat pendidikan, dukungan dari atasan, keanggotaan dalam mayoritas atau basis kekuatan lainnya, yang meliputi keahlian, kharisma, reward, atau kekuasaan koersif. Dengan demikian, individu yang mempunyai power lebih tinggi akan lebih berkuasa dan dapat menekan individu yang tidak mempunyai power atau yang memiliki power lebih rendah dalam organisasi. Data deskriptif menunjukkan nilai rata-rata 9,7. Hal ini berarti mahasiswa tidak menganggap seorang atasan tidak begitu memiliki power yang besar terhadap dirinya. Hasil analisis menunjukkan hubungan status pelanggar tidak signifikan berpengaruh terhadap niat pelaporan kecurangan dengan jalur internal. Temuan ini didukung oleh Gao, Greenberg \& Wong-On-Wing (2015) yang menyatakan bahwa status pelaku kecurangan tidak signifikan berpengaruh terhadap niat pelaporan kecurangan. Sebaliknya tidak sejalan dengan temuan Cortina \& Magley (2003) dan Winardi, (2015). Dukungan organisasi dapat didefinisikan sebagai keyakinan karyawan mengenai sejauh mana organisasi menghargai kontribusi dan kepedulian mereka terhadap kesejahteraan mereka (Eisenberger et al., 2016).

Penelitian ini menunjukkan bahwa mahasiswa yang sudah bekerja cenderung memilih pentingnya perlindungan daripada dukungan organisasi terhadap apa yang akan mereka lakukan jika melaporkan kecurangan yang ditemukan. Dilihat dari data deskriptif dukungan organisasi berada di angka rata-rata. Hal ini menunjukkan bahwa kurangnya dukungan organisasi untuk melakukan pelaporan kecurangan. Sebagaimana yang dinyatakan oleh (Near \& Miceli, 1986) bahwa kurangnya dukungan dari pengawas dan manajemen puncak mengurangi niat individu untuk melakukan whistleblowing. Sedangkan hasil perlindungan organisasi signifikan berpengaruh terhadap niat pelaporan kecurangan dengan jalur internal. Para pemimpin etis yang mendukung dan mendorong perilaku etis memfasilitasi motivasi untuk pelaporan kecurangan (Bhal \& Dadhich, 2011; Taylor \& Curtis, 2013). Hal ini akan mengurangi dampak yang akan didapatkan oleh pelapor jika terdapat perlindungan dari organisasi. Sebagaimana yang dinyatakan oleh Cho \& Song (2015) ketika organisasi memprioritaskan pentingnya whistleblowing dan memutuskan untuk sepenuhnya melindungi whistleblower, upaya tersebut dapat dianggap sebagai jenis dukungan organisasi, yang akan memfasilitasi whistleblowing dengan mengurangi biaya kerugian pribadi yang dirasakan.

\section{SIMPULAN}

Penelitian ini menguji faktor persepsi kerugian pribadi, status pelanggar, dukungan dan proteksi organisasi terhadap niat pelaporan kecurangan internal. Responden penelitian ini adalah 112 mahasiswa akuntansi yang sudah bekerja baik sektor swasta maupun pemerintahan di DKI Jakarta. Secara deskriptif dapat dijelaskan bahwa partisipasi responden menjadi whistleblower masih tergolong rendah. Hal ini dapat disebabkan oleh berbagai faktor, seperti persepsi kerugian pribadi dan status pelanggar. Di sisi lain, terdapat factor yang memungkinkan karyawan untuk melaporkan kecurangan, seperti dukungan dan proteksi organisasi.

Hasil penelitian menunjukkan bahwa hanya perlindungan organisasi yang signifikan berpengaruh terhadap niat pelaporan kecurangan internal. Ketika karyawan mendapatkan fasilitas rasa aman maka akan mempengaruhi niat mereka dalam mengambil keputusan etis. Oleh sebab itu perlindungan organisasi dapat berpengaruh signifikan terhadap niat pelaporan kecurangan dengan jalur internal. Sedangkan persepsi kerugian pribadi, status pelanggar, dan dukungan organisasi tidak signifikan berpengaruh terhadap niat pelaporan kecurangan internal. Hasil penelitian ini terbukti memberikan implikasi bahwa perlindungan dari organisasi adalah hal paling penting bagi calon pelapor kecurangan. Hal ini juga dapat menjadi pertimbangan bagi pemerintah untuk mempertimbangkan peraturan khusus mengenai whistleblowing dan perlindungan terhadap pelapor. Sebagaimana pemerintahan di Amerika memiliki peraturan yang memadai dalam melindungi pelapor kecurangan, 
seperti Sarbanes-Oxley Act dan the DoddFrank Act.

\section{KETERBATASAN DAN SARAN}

Responden penelitian ini adalah berasal dari mahasiswa S1 yang bekerja dan memiliki pengalaman yang terbatas. Pengujian pada responden yang telah memiliki pengalaman bekerja lebih lama dapat memberikan hasil penelitian yang berbeda. Oleh sebab itu, penelitian selanjutnya disarankan untuk menguji kembali pada responden mahasiswa yang telah memiliki pengalaman bekerja lebih lama, atau menguji pada mahasiswa strata dua untuk memperoleh penjelasan yang lebih baik. Penelitian di masa datang juga dapat merumuskan metode yang berbeda, misal metode eksperimen dengan memberikan treatment pada responden dalam rangka memperoleh penjelasan yang lebih baik mengenai faktor yang memengaruhi pelaporan kecurangan.

\section{DAFTAR PUSTAKA}

ACFE. (2016). Report to the nations on occupational fraud and abuse 2016. In ACFE Report.

Ahmad, S., Smith, G., \& Ismail, Z. (2012). Internal whistle-blowing intentions: A study of demographic and individual factors. Journal of Modern Accounting and Auditing, 8(11), 1632-1645.

Akbar, T., Suhernita, \& Yonnedi, E. (2016). Pengaruh saluran pelaporan pelanggaran dan personal cost terhadap minat untuk melaporkan kecurangan pada pengadaan barang/jasa pemerintah. Paper dipresentasikan pada acara Simposium Nasional Akuntansi XIX, 1-25.

Aliyah, S., Yang, A.F., Minat, M., Dalam, P., \& Whistle-blowing, M.T. (2015). Analisis faktor-faktor yang mempengaruhi minat pegawai dalam melakukan tindakan whistle-blowing. Universitas Islam Nahdlatul Ulama, Fakultas Ekonomi dan Bisnis, Jepara, 12(2).

Alleyne, P., Hudaib, M., \& Pike, R. (2013). Towards a conceptual model of whistle-blowing intentions among external auditors. British Accounting Review, 45(1), 10-23.

Andon, P., Free, C., Jidin, R., Monroe, G.S., \& Turner, M.J. (2018). The impact of financial incentives and perceptions of seriousness on whistleblowing in- tention. Journal of Business Ethics, 151(1), 165-178.

Banks, L.J., \& Filoromo, M.A. (2020). The SEC whistleblower practice guide: 9th Edition.

Baumert, A., Halmburger, A., \& Schmitt, M. (2013). Interventions against norm violations: dispositional determinants of self-reported and real moral courage. Personality and Social Psychology Bulletin, 39(8), 1053-1068.

Bhal, K.T., \& Dadhich, A. (2011). Impact of ethical leadership and leadermember exchange on whistle blowing: The moderating impact of the moral intensity of the issue. Journal of Business Ethics, 103(3), 485-496.

Bjørkelo, B. (2013). Workplace bullying after whistleblowing: Future research and implications Martin. Journal of Managerial Psychology, 28(3), 306323.

Bocchiaro, P., Zimbardo, P.G., \& van Lange, P.A.M. (2012). To defy or not to defy: An experimental study of the dynamics of disobedience and whistleblowing. Social Influence, 7(1), 35-50.

Brief, A., \& Motowidlo, S.J. (1986). Prosocial organizational behaviors. Academy of Management Stable, 11(4), 710725.

Brink, A.G., Cereola, S.J., \& Menk, K.B. (2015). The effects of personality traits, ethical position, and the materiality of fraudulent reporting on entry-level employee whistleblowing decisions. Journal of Forensic \& Investigative Accounting, 7(1), 180-211.

Brink, A.G., Lowe, D.J., \& Victoravich, L.M. (2013). The effect of evidence strength and internal rewards on intentions to report fraud in the doddfrank regulatory environment. Auditing, 32(3), 87-104.

Brink, A.G., Lowe, D.J., \& Victoravich, L.M. (2017). The public company whistleblowing environment: Perceptions of a wrongful act and monetary attitude. Accounting and the Public Interest, 17(1), 1-30.

Busra, N.F., Ahyaruddin, M., \& Agustiawan, A. (2019). Pengaruh tingkat keseriusan kecurangan, personal cost, dan komitmen organisasi terhadap kecenderungan melakukan whistleblowing. Muhammadiyah Riau Accounting and Business Journal, 1 (1), 011-019.

Cailleba, P., \& Charreire Petit, S. (2018). The whistleblower as the personification of a moral and managerial paradox. 
M@n@gement, 21(1),75-690.

Cassematis, P.G., \& Wortley, R. (2013). Prediction of whistleblowing or nonreporting observation: The Role of personal and situational factors. Journal of Business Ethics, 117(3), 615 -634 .

Chang, Y., Wilding, M., \& Shin, M.C. (2017). Determinants of whistleblowing intention: Evidence from the South Korean Government. Public Performance and Management Review, 40 (4), 676-700.

Cho, Y.J., \& Song, H.J. (2015). Determinants of whistleblowing within government agencies. Public Personnel Management, 44(4), 450-472.

Cortina, L.M., \& Magley, V.J. (2003). Raising voice, risking retaliation: Events following interpersonal mistreatment in the workplace. Journal of Occupational Health Psychology, 8(4), 247-265.

Dalton, D., \& Radtke, R.R. (2013). The joint effects of machiavellianism and ethical environment on whistle-blowing. Journal of Business Ethics, 117(1), 153 -172 .

Dozier, J.B., \& Miceli, M.P. (1985). Potential predictors of whistle-blowing. A prosocial behavior perspective. Academy of Management Review, 10(4), 823836.

Dungan, J.A., Young, L., \& Waytz, A. (2019). The power of moral concerns in predicting whistleblowing decisions. Journal of Experimental Social Psychology, 85(July), 103848.

Dyck, A., Morse, A., \& Zingales, L. (2010). Who blows the whistle on corporate fraud? Journal of Finance, 65(6), 2213-2253.

Eisenberg, N., Lennon, R., \& Roth, K. (1983). Prosocial development: A longitudinal study. Developmental Psychology, 19(6), 846-855.

Eisenberger, R., Malone, G.P., \& Presson, W.D. (2016). Optimizing perceived organizational support to enhance employee engagement. Society for Human Resource Management and Society for Industrial and Organizational Psychology, 2, 1-22.

Gao, J., Greenberg, R., \& Wong-On-Wing, B. (2015). Whistleblowing intentions of lower-level employees: The effect of reporting channel, bystanders, and wrongdoer power status. Journal of Business Ethics, 126(1), 85-99.

Graham, J. W. (1986). Principled organizational dissent: A theoretical essay. Research in Organizational Be- havior, 8, 1-52.

Greenberger, D.B., Miceli, M.P., \& Cohen, D.J. (1987). Oppositionists and group norms: The reciprocal influence of whistle-blowers and co-workers. Journal of Business Ethics, 6(7), 527542.

Hair, J. F., Anderson, R. E., Babin, B. J., \& Black, W. C. (2010). Multivariate data analysis: A global perspective (Vol. 7): Pearson Upper Saddle River.

Hanif, A \& Odiatma, F. (2017). Pengaruh personal cost reporting, status wrong doer dan tingkat keseriusan kesalahan terhadap whistleblowing intention rheny. Jurnal Akuntansi Keuangan dan Bisnis, 10(1), 11-20.

Helmayunita, N. (2018). The influence of personal cost of reporting, organizational commitment, fraud seriousnesss level, and gender on whistleblowing intentions. Paper dipresentasikan pada acara Piceeba, 57, 42-49.

Indriani, M., Yulia, A., Nadirsyah, N., \& Ariska, L.P. (2019). Whistleblowing intention, personal cost, organizational commitment and fraud seriousness level. Journal of Accounting and Investment, 20(2).

Jogiyanto, H. (2011). Konsep dan Applikasi Structural Equation Modeling Berbasis Varian Dalam Penelitian Bisnis, Yogyakarta, Indonesia: STIM YKPN.

Kammeyer-Mueller, J.D., Simon, L.S., \& Rich, B.L. (2012). The psychic cost of doing wrong: Ethical conflict, divestiture socialization, and emotional exhaustion. Journal of Management, 38(3), 784-808.

Kaplan, S.E., Pany, K., Samuels, J., \& Zhang, J. (2012). An examination of anonymous and non-anonymous fraud reporting channels. Advances in Accounting, 28(1), 88-95.

Kenny, K., Fotaki, M., \& Scriver, S. (2019). Mental heath as a weapon: Whistleblower retaliation and normative violence. Journal of Business Ethics, 160 (3), 801-815.

Lavena, C.F. (2014). Whistle-Blowing: Individual and Organizational determinants of the decision to report wrongdoing in the federal government. American Review of Public Administration, 46(1), 113-136.

Liyanarachchi, G., \& Newdick, C. (2009). The impact of moral reasoning and retaliation on whistle-blowing: New Zealand evidence. Journal of Business Ethics, 89(1), 37-57.

Mesmer-Magnus, J.R., \& Viswesvaran, C. 
(2005). Whistleblowing in organizations: An examination of correlates of whistleblowing intentions, actions, and retaliation. Journal of Business Ethics, 62(3), 277-297.

Near, J.P., \& Miceli, M.P. (1986). Retaliation against whistle blowers. Predictors and effects. Journal of Applied Psychology, 71(1), 137-145.

Near, J.P., \& Miceli, M.P. (1995). Effective Whistle-Blowing. 20(3), 679-708.

Nurkholis, R.B. (2015). Faktor-faktor yang mempengaruhi minat pegawai negeri sipil (PNS) untuk melakukan tindakan whistleblowing (Studi pada PNS BPK RI). Jurnal Ekonomi dan Keuangan, 19(2), 276-295.

O'Sullivan, P., \& Ngau, O. (2014). Whistleblowing: A critical philosophical analysis of the component moral decisions of the act and some new perspectives on its moral significance. Business Ethics, 23(4), 401-415.

Park, H., Blenkinsopp, J., Oktem, M.K., \& Omurgonulsen, U. (2008). Cultural orientation and attitudes toward different forms of whistleblowing: A comparison of South Korea, Turkey, and the U.K. Journal of Business Ethics, 82(4), 929-939.

Pope, K.R., \& Lee, C.C. (2013). Could the Dodd-Frank Wall Street Reform and Consumer Protection Act of 2010 be helpful in Reforming Corporate America? An Investigation on Financial Bounties and Whistle-Blowing behaviors in the Private Sector. Journal of Business Ethics, 112(4), 597607.

Rose, J.M., Brink, A.G., \& Norman, C.S. (2018). The effects of compensation structures and monetary rewards on managers' decisions to blow the whistle. Journal of Business Ethics, 150(3), 853-862.

Saud, I.M., \& Fauzi, A. (2019). The Effect of Rewards, Personal Costs, and The Whistleblowing System Toward Individual Intentions to Report Unethical Behaviors of Superiors. Paper dipresentasikan pada acara Icaf, 102, 9197.

Saud, M.I. (2016). Pengaruh sikap dan persepsi kontrol perilaku terhadap niat whistleblowing internal-eksternal dengan persepsi dukungan organisasi sebagai variabel pemoderasi. Jurnal Akuntansi dan Investasi, 17(2), 209-219.

Schultz, J.J., Johnson, D.A., Morris, D., \& Dyrnes, S. (1993). An investigation of the reporting of questionable acts in an international setting. Journal of Accounting Research, 31, 75.

Semendawai, A.H., Santoso, F., Wagiman, W., Omas, B.I., Susilaningtias, \& Wiryawan, S.M. (2011). Memahami Whistleblower. Jakarta: LPSK Indonesia.

Setyawati, I., Ardiyani, K., \& Sutrisno, C.R. (2015). Faktor-faktor yang mempengaruhi niat untuk melakukan whistleblowing internal (The factors influencing internal whistleblowing intentions). Jurnal Ekonomi dan Bisnis, 17(2), 22-33.

Skitka, L.J. (2012). Moral convictions and moral courage: Common denominators of good and evil. The Social Physicology of Morality, 349-365.

Stubben, S.R., \& Welch, K.T. (2020). Evidence on the use and efficacy of internal whistleblowing systems. Journal of Accounting Research, 58(2), 473-518.

Taylor, E.Z., \& Curtis, M.B. (2013). Whistleblowing in audit firms: Organizational response and power distance. Behavioral Research in Accounting, 25 (2), 21-43.

Ugaddan, R.G., \& Park, S.M. (2019). Do trustful leadership, organizational justice, and motivation influence whistle-blowing intention? Evidence from federal employees. Public Personnel Management, 48(1), 56-81.

Urumsah, D., Wicaksono, A.P., \& Hardinto, W. (2018). Pentingkah nilai religiusitas dan budaya organisasi untuk mengurangi kecurangan? Jurnal Akuntansi Multiparadigma, 9(1), 156172.

Utami, W., \& Indriawati, F. (2006). Muatan etika dalam pengajaran akuntansi keuangan dan dampaknya terhadap persepsi etika mahasiswa: Studi eksperimen semu. Paper dipresentasikan pada acara Simposium Nasional Akuntansi IX Padang, 23-26.

Valentine, S., \& Godkin, L. (2019). Moral intensity, ethical decision making, and whistleblowing intention. Journal of Business Research, 98(January), 277288.

van der Velden, P.G., Pecoraro, M., Houwerzijl, M.S., \& van der Meulen, E. (2019). Mental health problems among whistleblowers: A comparative study. Psychological Reports, 122(2), 632-644.

Watts, L.L., \& Ronald Buckley, M. (2015). A dual-processing model of moral whistleblowing in organizations. Journal of Business Ethics, 146(3), 669 
JURNAL AKUNTANSI DAN BISNIS Vol. 20, No. 2, Agustus 2020: 186-201

$-683$.

Watts, L.L., \& Ronald Buckley, M. (2017). A dual-processing model of moral whistleblowing in organizations. Journal of Business Ethics, 146(3), 669 $-683$.

Weaver, G.R., Reynolds, S.J., \& Brown, M.E. (2014). Moral intuition: Connecting current knowledge to future organizational research and practice. Journal of Management, 40(1).

Winardi, R.D. (2015). The Influence of individual and situational factors on low- er-level civil servants' whistleblowing intention in Indonesia. Jurnal Ekonomi \& Bisnis Indonesia (Fakultas Ekonomi dan Bisnis Universitas Gadjah Mada), 28(3), 361-376.

Zamzami, A.H., Safira, S., \& Mahmudah, H. (2020). Whistleblowing intention: A study of situation factors. SSRN Electronic Journal, 6(12), 132-140.

Zhang, J., Pany, K., \& Reckers, P.M.J. (2013). Under which conditions are whistleblowing "best practices" best? Auditing, 32(3), 171-181. 